\title{
Antibody Response to Paramyxoviruses in Paget's Disease of Bone
}

\author{
Micaela Rios Visconti ${ }^{1} \cdot$ Ricardo Usategui-Martín $^{1} \cdot$ Stuart H. Ralston $^{1}$
}

Received: 29 January 2017 / Accepted: 2 March 2017 / Published online: 31 March 2017

(C) The Author(s) 2017. This article is an open access publication

\begin{abstract}
Paget's disease of bone (PDB) is a common skeletal disorder characterised by focal abnormalities of increased and disorganised bone turnover. Genetic factors play a central role in the pathogenesis of PDB but environmental factors also contribute. Measles virus (MV), respiratory syncytial virus (RSV) and canine distemper virus (CDV) have all been implicated as potential disease triggers but the data are conflicting. Since chronic paramyxovirus infection with measles is known to be accompanied by increased production of antiviral antibodies, we have analysed circulating concentrations of antibodies to MV, $\mathrm{CDV}$, and RSV as well as mumps, rubella and varicella zoster virus (VZV) in 463 patients with PDB and 220 aged and gender-matched controls. We also studied the relation between viral antibody concentrations and various markers of disease severity and extent in 460 PDB patients. A high proportion of cases and controls tested positive for antiviral antibodies but there was no significant difference in circulating antibody concentrations between PDB cases and controls for MV, CDV, RSV, rubella or VZV. However, mumps virus antibody levels were significantly higher in the PDB cases (mean $\pm \mathrm{SD}=3.1 \pm 0.84$ vs. $2.62 \pm 0.86 . p<0.001$ ). There was no association between disease severity and circulating antibody concentrations to any of the viruses. In conclusion, we found no evidence to suggest that PDB is associated with abnormalities of immune response to measles or other paramyxoviruses, although there was evidence of a greater antibody response to mumps. The results do
\end{abstract}

Stuart H. Ralston

stuart.ralston@ed.ac.uk

1 The Centre for Genomic and Experimental Medicine, MRC Institute of Genetics and Molecular Medicine, Western General Hospital, University of Edinburgh, Edinburgh EH4 2XU, UK not support that hypothesis that PDB is associated with a persistent infection with measles or other paramyxoviruses.

Keywords Paget's disease of bone - Paramyxovirus . Measles · Distemper · Genetic

\section{Introduction}

Paget's disease of bone is a common skeletal disorder characterised by focal abnormalities of increased and disorganised bone turnover at one or more skeletal sites [1]. Many patients are asymptomatic but those that do come to clinical attention can develop various complications including bone pain, deformity, pathological fractures, osteoarthritis, deafness and rarely osteosarcoma [2,3]. Paget's disease is a complex disorder. Current evidence suggests that genetic factors play a key role in susceptibility [4], but there is also a strong environmental component evidenced by the fact that the disease has become less common and less severe in several countries over recent decades [5-7]. Several potential environmental triggers for Paget's disease of bone (PDB) have been suggested including dietary calcium intake [8], vitamin D deficiency [9] and excessive biomechanical loading of affected bones [10], but the most widely studied is paramyxovirus infection $[11,12]$. Paramyxoviruses were first implicated as a potential trigger of PDB by the morphological finding of nuclear inclusion bodies in osteoclast nuclei which were thought to resemble measles nucleocapsids $[13,14]$. Despite extensive research over the past 30 years, the role of paramyxovirus infection in the pathogenesis of PDB remains controversial $[15,16]$. Some researchers have reported finding evidence of measles virus (MV) nucleic acids or antigens in cells and tissues from patients with the disease [17-20]. Respiratory 
syncytial virus antigens were also detected in one study [21], and in another evidence was presented to suggest that antigens for both MV and respiratory syncytial virus (RSV) may be present [22]. Canine distemper virus (CDV) nucleic acids have also been reported by one group to be present in Pagetic bone cells [23, 24], whereas other researchers failed to find evidence of paramyxovirus nucleic acids or protein in bone tissue or peripheral blood from PDB patients [15, 25-29]. A characteristic feature of the persistent measles infection, subacute sclerosing panencephalitis, is the presence of a marked increase in antiviral antibodies both in the serum and cerebrospinal fluid [30, 31]. Based on this observation, several researchers have measured antibodies to paramyxoviruses in patients with PDB [32-35]. These studies yielded negative results, but the sample sizes were small and had limited power to detect possible differences between PDB cases and controls. Here, we have evaluated the antibody response to paramyxoviruses in PDB in the largest study performed to date using a case control design and determined if antibody concentrations were associated with disease extent or complications. We also evaluated the antibody response to other common viral infections not previously implicated in the pathogenesis of PDB including mumps, rubella and varicella zoster virus.

\section{Patients and Methods}

\section{Patients}

The study cohort comprised 463 patients who participated in the Paget's disease, Randomised Trial of Intensive versus Symptomatic Management (PRISM) study (ISRCTN12989577) [36, 37]. Participants were included in this study if sufficient serum was available from the baseline study visit for analysis of the antibodies of interest. One subject included in this study had a history of osteosarcoma. The controls comprised 202 age and gender match subjects not known to have PDB who were predominantly spouses of PRISM participants.

\section{Clinical Assessments}

The clinical assessments performed within the PRISM study have been previously described [36]. Health-related quality of life was assessed by the SF-36 questionnaire. Deformity was assessed by the attending physicians who were asked to assess whether the patient had clinical evidence of bone deformity using a three-point scale as follow: $0=$ no deformity; $1=$ mild or moderate deformity and $2=$ severe deformity. The presence of bone pain was recorded and physicians were asked to assess if they thought the pain was caused by PDB. Information was collected on previous fractures and whether they had occurred in affected bone; on orthopaedic surgical procedures; on the use of a hearing aid for deafness in those with skull disease; on age at first diagnosis of PDB; and family history of PDB. The extent of PDB was recorded based on involvement on bone scan examination. Information was recorded on previous bisphosphonate treatment, and the number of treatment courses given. Based on the clinical data, we devised a composite scoring system for disease severity as previously described [38] taking into account the number of affected bones, age at first diagnosis, family history, presence of bone pain, pathological fracture, orthopaedic surgery for PDB, bone deformity, deafness associated with skull involvement and previous bisphosphonate treatment for PDB.

\section{Genotyping}

Genotyping was conducted for SQSTM1 mutations by DNA sequencing on DNA extracted from peripheral blood using standard techniques as previously described [38].

\section{Detection of Antiviral Antibodies}

Enzyme-linked immunosorbent assays (ELISA) were used for the detection and quantitative determination of $\operatorname{IgG}$ antibodies to MV, Rubella, Mumps, Varicella Zoster Virus (VZV), RSV and CDV. The ELISA were performed on serum samples that had been collected at the baseline visit of the PRISM study between 2001 and 2004 and stored frozen at $-80^{\circ} \mathrm{c}$ until analysis in the present study. We used the Trinity Biotech Captia assays ${ }^{\mathrm{TM}}$ for MV (catalogue number 2326000), mumps (catalogue number 2325900) rubella (catalogue number 2325300) and VZV (catalogue number 2325600). We used the MP Biomedical IgG ELISA (catalogue number 071-516002) for RSV. For CDV, we used the ImmunoComb ${ }^{\circledR}$ antibody test kit. All assays were performed according to the manufacturer's instructions. The results of the ELISA assays were read on a Synergy HT Multi-Mode Micro plate reader (Bio-Tek), $450 \mathrm{~nm}$ filter. Dual wavelength was used and the reference filter set to $600-650 \mathrm{~nm}$. All samples were tested in duplicate and the mean value of the two samples calculated. Duplicate samples that yielded values that differed by more than $20 \%$ were repeated. With the exception of CDV, data were expressed as the immune status ratio (ISR). This was calculated by dividing the optical density value of the patient sample by a calibrator value provided with the kit. These results were converted to International Units (IU) using the natural exponential function $f(x)=\mathrm{e}^{x}$. For CDV, semiquantitative analysis was performed based on a colour scale provided with the kit using Comb Scan software. The reference ranges are shown in Table 1. 
Table 1 Reference ranges for viral antibodies

\begin{tabular}{llll}
\hline Virus & Negative & Indeterminate & Positive \\
\hline Measles & $\leq 0.06$ & $0.061-0.09$ & $\geq 0.091$ \\
Mumps & $\leq 0.9$ & $0.91-1.09$ & $\geq 1.10$ \\
Rubella & $\leq 6.5$ & $6.6-8.1$ & $\geq 8.2$ \\
Varicella zoster & $\leq 0.11$ & $0.12-0.14$ & $\geq 0.15$ \\
Respiratory syncytial virus & $\leq 0.54$ & $0.55-1.09$ & $\geq 1.10$ \\
Canine distemper & 0 & $1-2$ & $\geq 3$ \\
\hline
\end{tabular}

Values are in international units with the exception of CDV which are arbitrary units. Negative results indicate that there is no serological evidence of previous infection; positive results indicate a previous infection; values in between are indeterminate

\section{Statistical Analysis}

Differences in viral antibody concentrations in PDB cases and controls were assessed quantitatively using Student's $t$-test and semi-quantitatively by $\chi^{2}$ test in which patients were categorised into two groups if antibody concentrations suggested there had been previous infection. The relation between viral antibody titres and disease extent was evaluated by dividing PDB subjects into three groups based on the severity score and comparing viral antibody titres and other clinical characteristics between the groups by ANOVA or $\chi^{2}$ test as appropriate. The significance level was set at 0.008 to account for the fact that antibodies against six different viruses were tested.

\section{Results}

\section{Antiviral Antibodies in PDB Cases and Controls}

Demographic characteristics and antiviral antibody concentrations in PDB cases and controls are shown in Table 2. A high proportion of PDB cases and controls tested positive for measles virus, rubella, VZV, mumps and RSV indicating previous infection, with no significant difference between the groups. All cases and controls tested positive for at least one virus and more than $90 \%$ tested positive for four of the viruses. Antibodies were also detected that cross-reacted with distemper virus in about $45 \%$ of PDB cases and controls with no difference between the groups. Quantitative analysis showed that antibody concentrations did not differ between cases and controls for MV, CDV, RSV and VZV (Table 2). However, antibody concentrations for mumps virus were significantly higher in PDB cases as compared with controls $(3.00 \pm 0.85$ vs. $2.56 \pm 0.89 ; p<0.001)$. For rubella virus, antibody concentrations in PDB cases were also higher, but this was not significant taking multiple testing into account $(29.1 \pm 11.4$ vs. $27.30 \pm 9.82, p=0.039$ ).
Relation Between Severity of PDB and Antiviral Antibodies

To determine if circulating antibody concentrations were related to the severity of PDB, patients were grouped into three categories based on the disease severity score as previously described [38]. Mild disease was defined as a score of 3 or less, moderate disease as a score of 4 to 6 and severe disease as a score of 7 or more. The result is shown in Table 3. There was no association between disease severity and circulating antibody concentrations to any of the viruses tested. We repeated the analysis for number of affected bones but no association was observed (data not shown). The presence of SQSTM1 mutations was associated with greater severity. Not surprisingly, patients with more severe disease had a significantly lower physical functioning as assessed by the SF36 instrument. Interestingly, there was difference between the severity groups in SF36 bodily pain or mental functioning. The patient with a history of osteosarcoma tested positive for all the viruses studied, except CDV where the results were negative. The circulating antibody concentrations were unremarkable in this patient.

\section{Antiviral Antibodies and SQSTM1 Mutations}

It has previously been suggested that measles virus infection may interact with SQSTM1 mutations to act as a trigger for PDB [39]. To determine whether antibody concentrations were associated with SQSTMI mutation status, we performed a subgroup analysis in which we analysed circulating antibody concentrations in SQSTMI mutation positive and negative PDB cases as compared with controls. The results are summarised in Table 4. There was no difference in circulating antibody concentration to any of the viruses tested according to SQSTM1 mutation status, although concentration of mumps virus antibodies were higher in SQSTM1 negative and SQSTM1 positive PDB cases as compared with SQSTM1 negative controls.

\section{Discussion}

The aim of this study was to determine if antibody response to measles virus, RSV or distemper virus was associated with the occurrence or severity of PDB. In addition to testing for antibodies to the paramyxoviruses which have previously been implicated in PDB [11, 12, 22], we also measured antibody concentrations to other common viruses such as mumps, rubella and varicella zoster virus.

The results showed that a high proportion of patients in both the PDB group and the control group had circulating antibodies to the viruses tested indicating that previous 
Table 2 Clinical characteristics and antibody concentrations in PDB cases and controls

\begin{tabular}{|c|c|c|c|}
\hline & $\mathrm{PDB}(n=463)$ & Controls $(n=221)$ & $p$-value \\
\hline Age (years) & $72.4 \pm 8.0$ & $72.2 \pm 8.4$ & 0.75 \\
\hline Male & $240(51.8 \%)$ & $114(51.5 \%)$ & 0.95 \\
\hline Age at diagnosis & $64.3 \pm 10.5$ & - & \\
\hline Family history PDB & $70(15.1 \%)$ & - & \\
\hline SQSTM1 mutation & $38(8.4 \%)$ & & \\
\hline Number of affected sites & & - & \\
\hline 1 & $222(47.1 \%)$ & & \\
\hline 2 & $141(30.4 \%)$ & & \\
\hline 3 & $62(13.4 \%)$ & & \\
\hline$>4$ & $38(8.2 \%)$ & & \\
\hline Fractures in pagetic bone & $47(10.1 \%)$ & & \\
\hline Orthopaedic surgery & $83(17.9 \%)$ & & \\
\hline Previous bisphosphonate & $353(76.2 \%)$ & - & \\
\hline Deafness and skull involvement & $34(7.3 \%)$ & & \\
\hline Bone deformity & $172(37.1 \%)$ & & \\
\hline Bone pain & $345(74.5 \%)$ & & \\
\hline Adjusted alkaline phosphatase & $1.18 \pm 1.01$ & - & \\
\hline \multicolumn{4}{|l|}{ Measles virus } \\
\hline Antibody concentration (IU/ml) & $3.00 \pm 12.3$ & $2.32 \pm 6.16$ & 0.36 \\
\hline Previous infection & $459(99.1 \%)$ & $217(98.2 \%)$ & 0.28 \\
\hline \multicolumn{4}{|l|}{ Respiratory syncytial virus } \\
\hline Antibody concentration (IU/ml) & $227 \pm 144$ & $220 \pm 143$ & 0.57 \\
\hline Positive serology & $425(91.8 \%)$ & $204(92.3 \%)$ & 0.881 \\
\hline \multicolumn{4}{|l|}{ Canine distemper virus } \\
\hline Antibody concentration (IU/ml) & $2.37 \pm 1.08$ & $2.39 \pm 1.16$ & 0.79 \\
\hline Positive serology & $208(45.1 \%)$ & $100(45.2 \%)$ & 1.00 \\
\hline \multicolumn{4}{|l|}{ Mumps virus } \\
\hline Antibody concentration (IU/ml) & $3.00 \pm 0.85$ & $2.56 \pm 0.89$ & 0.0001 \\
\hline Positive serology & $451(97.4 \%)$ & $210(95.0 \%)$ & 0.11 \\
\hline \multicolumn{4}{|l|}{ Varicella zoster virus } \\
\hline Antibody concentration (IU/ml) & $0.872 \pm 0.728$ & $0.784 \pm 0.741$ & 0.147 \\
\hline Positive serology & $448(96.8 \%)$ & $215(97.3 \%)$ & 0.81 \\
\hline \multicolumn{4}{|l|}{ Rubella virus } \\
\hline Antibody concentration (IU/ml) & $29.1 \pm 11.4$ & $27.30 \pm 9.82$ & 0.039 \\
\hline Positive serology & $451(97.4 \%)$ & $215(97.3 \%)$ & 1.00 \\
\hline
\end{tabular}

The values shown are mean SD and number (\%). The $p$-values refer to differences between cases and controls assessed by Students $t$-test, Fishers exact test or $\chi^{2}$ test. For MV, RSV, Mumps, VZV and Rubella participants were coded as having positive serology when antibody concentrations were above the reference range suggested by the manufacturer as indicating previous infection. Information on antibody concentrations for CDV was missing for two PDB patients. For CDV, subjects who tested positive or high were considered to have positive serology infection had occurred. For most viruses, the prevalence of those that tested positive was greater than $95 \%$ with no difference between cases and controls. These results confirm the findings of previous small scale studies which failed to find a difference in antiviral antibody concentrations between PDB cases and controls [32-35]. For CDV, only about $45 \%$ of cases and controls tested positive. Since there is extensive homology within the paramyxovirus family [40-44], it is unclear if these antibodies truly represented previous distemper virus infection or were cross reacting antibodies due to exposure to other paramyxoviruses such as measles [45]. Further studies will be required to investigate this fully. On quantitative testing, there was no significant difference in circulating antibody concentrations between cases and controls except for mumps virus where concentrations were significantly higher in cases. This raises the possibility that the immune response to mumps may be altered in PDB 
Table 3 Antiviral antibodies and other variables in relation to severity of PDB

\begin{tabular}{|c|c|c|c|c|}
\hline & Mild PDB $(n=152)$ & Moderate PDB $(n=163)$ & Severe PDB $(n=145)$ & $p$-value \\
\hline Age (years) & $74.7 \pm 6.2$ & $71.2 \pm 8.6$ & $71.5 \pm 8.6$ & $<0.0001$ \\
\hline Male gender & $85(55.9 \%)$ & $78(47.8 \%)$ & $76(52.4 \%)$ & 0.35 \\
\hline Measles virus (IU/ml) & $4.5 \pm 18.6$ & $1.9 \pm 6.0$ & $2.4 \pm 8.9$ & 0.13 \\
\hline Respiratory syncytial virus (IU/ml) & $224.5 \pm 147.9$ & $228.8 \pm 144.7$ & $227.5 \pm 141.6$ & 0.96 \\
\hline Canine distemper virus (IU/ml) & $2.40 \pm 1.11$ & $2.42 \pm 1.11$ & $2.24 \pm 1.01$ & 0.30 \\
\hline Mumps virus (UI/ml) & $2.96 \pm 0.91$ & $3.05 \pm 0.82$ & $3.0 \pm 0.81$ & 0.60 \\
\hline Varicella zoster virus (IU/ml) & $0.86 \pm 0.76$ & $0.88 \pm 0.66$ & $0.88 \pm 0.77$ & 0.95 \\
\hline Rubella virus (IU/ml) & $28.6 \pm 11.6$ & $30.0 \pm 12.0$ & $28.9 \pm 10.7$ & 0.38 \\
\hline SQSTM1 mutation & $3(2.0 \%)$ & $16(9.8 \%)$ & $20(13.8 \%)$ & 0.001 \\
\hline SF36 bodily pain & $40.2 \pm 10.9$ & $38.6 \pm 10.7$ & $38.0 \pm 10.5$ & 0.19 \\
\hline SF36 physical functioning & $38.1 \pm 11.0$ & $36.2 \pm 11.5$ & $34.3 \pm 10.4$ & 0.02 \\
\hline SF36 mental functioning & $47.9 \pm 11.0$ & $49.6 \pm 11.3$ & $47.7 \pm 11.8$ & 0.31 \\
\hline
\end{tabular}

Patients with mild PDB had a disease severity score of 3 or less, those with moderate a score of 4-6 and those with severe PDB a score of 7 or more. Values are mean \pm standard deviation or numbers (\%). The $p$-values refer to differences across groups, as assessed by ANOVA

Table 4 Antiviral antibodies in PDB cases and controls according to SQSTM1 status

\begin{tabular}{|c|c|c|c|c|}
\hline & $\begin{array}{l}\text { PDB SQSTM1 } \\
\text { +ve }(n=38)\end{array}$ & $\begin{array}{l}\text { PDB SQSTM1 - } \\
\text { ve }(n=425)\end{array}$ & $\begin{array}{l}\text { Control SQSTM1 } \\
\text {-ve }(n=221)\end{array}$ & $p$-value \\
\hline Age (years) & $71.1 \pm 6.1$ & $72.6 \pm 8.0$ & $72.2 \pm 8.6$ & 0.56 \\
\hline Male gender & $17(44.7 \%)$ & $223(52.5 \%)$ & $114(51.6 \%)$ & 0.65 \\
\hline \multicolumn{5}{|l|}{ Measles virus } \\
\hline Antibody concentration (IU/ml) & $2.65 \pm 8.8$ & $2.98 \pm 12.5$ & $2.31 \pm 6.2$ & 0.75 \\
\hline Previous infection & $38(100 \%)$ & $421(99.1 \%)$ & $217(98.2 \%)$ & 0.49 \\
\hline \multicolumn{5}{|l|}{ Respiratory syncytial virus } \\
\hline Antibody concentration (IU/ml) & $236.5 \pm 138.9$ & $225.9 \pm 144.7$ & $220.3 \pm 143.4$ & 0.78 \\
\hline Previous infection & $35(92.1 \%)$ & $390(91.8 \%)$ & $204(92.3 \%)$ & 0.97 \\
\hline \multicolumn{5}{|l|}{ Canine distemper virus } \\
\hline Antibody concentration (IU/ml) & $2.31 \pm 1.35$ & $2.37 \pm 1.05$ & $2.39 \pm 1.16$ & 0.91 \\
\hline Previous infection & $14(37.8 \%)$ & $194(45.7 \%)$ & $100(45.2 \%)$ & 0.64 \\
\hline \multicolumn{5}{|l|}{ Mumps virus } \\
\hline Antibody concentration (IU/ml) & $3.00 \pm 0.92$ & $3.00 \pm 0.84$ & $2.56 \pm 0.89$ & 0.0001 \\
\hline Previous infection & $37(97.4 \%)$ & $414(97.4 \%)$ & $210(95.0 \%)$ & 0.29 \\
\hline \multicolumn{5}{|l|}{ Varicella zoster virus } \\
\hline Antibody concentration (IU/ml) & $0.86 \pm 0.72$ & $0.87 \pm 0.73$ & $0.78 \pm 0.74$ & 0.34 \\
\hline Previous infection & $36(94.7 \%)$ & $412(96.9 \%)$ & $215(97.3 \%)$ & 0.73 \\
\hline \multicolumn{5}{|l|}{ Rubella virus } \\
\hline Antibody concentration (IU/ml) & $30.8 \pm 11.9$ & $28.9 \pm 11.4$ & $27.3 \pm 9.8$ & 0.09 \\
\hline Previous infection & $38(100 \%)$ & $413(97.2 \%)$ & $217(97.3 \%)$ & 0.35 \\
\hline
\end{tabular}

Values are mean \pm SD or number (\%). The $p$-values are from ANOVA for antibody concentrations and from $\chi^{2}$ test for the proportion of patients with previous infection. Information on antibody concentrations for CDV was missing for two PDB patients; one in the SQSTM1 positive and one in the SQSTM1 negative group

and suggests that the role of mumps in PDB might be worth further study.

We also sought to determine if the levels of virus antibody were associated with the severity of PDB. For this analysis, patients were divided into three categories of mild moderate and severe PDB based on disease extent and complications as previously described [38]. No significant association between circulating antibody levels and disease severity or extent was observed. Given that persistent virus infections such as SSPE are associated with high titres of antibody production [30, 31], this observation argues strongly against the possibility that there is a state of 
persistent paramyxovirus viral infection in PDB contrary to what has been suggested [46]. While the present study provides no support for the hypothesis that patients with PDB have persistent paramyxovirus infection, the study design cannot completely rule out the possibility that previous exposure to a viral illness early in life might play a role in PDB. However, as previously reported, there was a significant association between disease severity and the presence of SQSTM1 mutations [38, 47] emphasising the importance of genetic factors in the pathogenesis of PDB and its severity. In summary, the present study does not provide support for the notion that persistent paramyxovirus infection is involved in the pathogenesis of PDB.

Acknowledgements This work was supported by grants from Arthritis Research UK (17646 and 13724) and the Paget's Association (UK).

Author Contributions MR-V performed the experimental work, contributed to the design of the study, analysed the data and wrote the first draft of the paper. RU-M contributed to analysis and interpretation of the data and revised the manuscript. SHR obtained funding to support the study, contributed to design of the study, contributed to analysis and interpretation of the data and revised the manuscript.

\section{Compliance with Ethical Standards}

Conflict of interest SHR reports having received consulting fees on behalf of his institution from Novartis and Merck and research grants to his institution from Amgen, Eli Lilly, and UCB. The other authors have no interests to declare.

Human and Animal Rights and Informed Consent The trial was approved by the UK Multicentre Research Ethics Committee for Scotland (MREC01/0/53); by local ethical review boards in the participating study centres and by the Medicines \& Healthcare Products Regulatory Authority (CTA 21583/0002/001-0001). The study was included in the controlled clinical trials register (www.controlled-trials.com) and assigned the reference number ISRCTN12989577. All participants gave written informed consent to be included in the study.

Open Access This article is distributed under the terms of the Creative Commons Attribution 4.0 International License (http:// creativecommons.org/licenses/by/4.0/), which permits unrestricted use, distribution, and reproduction in any medium, provided you give appropriate credit to the original author(s) and the source, provide a link to the Creative Commons license, and indicate if changes were made.

\section{References}

1. Ralston SH (2013) Clinical practice. Paget's disease of bone. N Engl J Med 368:644-650

2. Tan A, Ralston SH (2014) Clinical presentation of Paget's disease: evaluation of a contemporary cohort and systematic review. Calcif Tissue Int 95:385-392

3. Sharma H, Jane MJ, Reid R (2005) Scapulo-humeral Paget's sarcoma: Scottish bone tumour registry experience. Eur J Cancer Care 14:367-372
4. Vallet M, Ralston SH (2016) Biology and treatment of Paget's disease of bone. J Cell Biochem 117:289-299

5. Cundy HR, Gamble G, Wattie D, Rutland M, Cundy T (2004) Paget's disease of bone in New Zealand: continued decline in disease severity. Calcif Tissue Int 75:358-364

6. Corral-Gudino L, Borao-Cengotita-Bengoa M, Del PinoMontes J, Ralston SH (2013) Epidemiology of Paget's disease of bone: a systematic review and meta-analysis of secular changes. Bone 55:347-352

7. Poor G, Donath J, Fornet B, Cooper C (2006) Epidemiology of Paget's disease in Europe: the prevalence is decreasing. J Bone Miner Res 21:1545-1549

8. Siris ES (1994) Epidemiological aspects of Paget's disease: family history and relationship to other medical conditions. Semin Arth Rheum 23:222-225

9. Barker DJ, Gardner MJ (1974) Distribution of Paget's diease in England, Wales and Scotland and a possible relationship with vitamin D deficiency in childhood. Br J Prev Soc Med 28:226-232

10. Solomon LR (1979) Billiard-player's fingers: an unusual case of Paget's disease of bone. Br Med J 1:931

11. Friedrichs WE, Reddy SV, Singer FR, Roodman GD (2002) The pro and con of measles virus in Paget's disease: pro. $\mathbf{J}$ Bone Miner Res 17:2293-2293

12. Mee AP (1999) Paramyxoviruses and Paget's disease: the affirmative view. Bone 24:19S-21S

13. Rebel A, Malkani K, Basle M, Bregeon C (1974) Particularites ultrastructurales des osteoclasts de la maladie de Paget. Rev Rhum Mal Osteoartic 41:767-771

14. Mills BG, Singer FR (1976) Nuclear inclusions in Paget's disease of bone. Science 194:201-202

15. Ralston SH, Afzal MA, Helfrich MH, Fraser WD, Gallagher JA, Mee A, Rima B (2007) Multicenter blinded analysis of RT-PCR detection methods for paramyxoviruses in relation to Paget's disease of bone. J Bone Miner Res 22:569-577

16. Rima BK, Gassen U, Helfrich MH, Ralston SH (2002) The pro and con of measles virus in Paget's disease: con. J Bone Miner Res 17:2290-2292

17. Reddy SV, Singer FR, Mallette L, Roodman GD (1996) Detection of measles virus nucleocapsid transcripts in circulating blood cells from patients with Paget disease. J Bone Miner Res 11:1602-1607

18. Reddy SV, Singer FR, Roodman GD (1995) Bone marrow mononuclear cells from patients with Paget's disease contain measles virus nucleocapsid messenger ribonucleic acid that has mutations in a specific region of the sequence. J Clin Endocrinol Metab 80:2108-2111

19. Basle MF, Fournier JG, Rozenblatt S, Rebel A, Bouteille M (1986) Measles virus RNA detected in Paget's disease bone tissue by in situ hybridization. J Gen. Virol 67(Pt 5):907-913

20. Basle MF, Russell WC, Goswami KK, Rebel A, Giraudon P, Wild F, Filmon R (1985) Paramyxovirus antigens in osteoclasts from Paget's bone tissue detected by monoclonal antibodies. J Gen Virol 66(Pt 10):2103-2110

21. Mills BG, Singer FR, Weiner LP, Holst PA (1981) Immunohistological demonstration of respiratory syncytial virus antigens in Paget's disease of bone. Proc Natl Acad Sci USA 78:1209-1212

22. Mills BG, Singer FR, Weiner LP, Suffin SC, Stabile E, Holst P (1984) Evidence for both respiratory syncytial virus and measles virus antigens in the osteoclasts of patients with Paget's disease of bone. Clin Orthop Relat Res 183:303-311

23. Gordon MT, Mee AP, Anderson DC, Sharpe PT (1992) Canine distemper transcripts sequenced from pagetic bone. Bone Miner 19:159-174 
24. Gordon MT, Anderson DC, Sharpe PT (1991) Canine distemper virus localised in bone cells of patients with Paget's disease. Bone 12:195-201

25. Ralston SH, DiGiovine FS, Gallacher SJ, Boyle IT, Duff GW (1991) Failure to detect paramyxovirus sequences in Paget's disease of bone using the polymerase chain reaction. J Bone Miner Res 6:1243-1248

26. Helfrich MH, Hobson RP, Grabowski PS, Zurbriggen A, Cosby SL, Dickson GR, Fraser WD, Ooi CG, Selby PL, Crisp AJ, Wallace RG, Kahn S, Ralston SH (2000) A negative search for a paramyxoviral etiology of Paget's disease of bone: molecular, immunological, and ultrastructural studies in UK patients. J Bone Miner Res 15:2315-2329

27. Birch MA, Taylor W, Fraser WD, Ralston SH, Hart CA, Gallagher JA (1994) Absence of paramyxovirus RNA in cultures of pagetic bone cells and in pagetic bone. $\mathrm{J}$ Bone Miner Res 9:11-16

28. Ooi CG, Walsh CA, Gallagher JA, Fraser WD (2000) Absence of measles virus and canine distemper virus transcripts in longterm bone marrow cultures from patients with Paget's disease of bone. Bone 27:417-421

29. Matthews BG, Afzal MA, Minor PD, Bava U, Callon KE, Pitto RP, Cundy T, Cornish J, Reid IR, Naot D (2008) Failure to detect measles virus RNA in bone cells from patients with Paget's disease. J Clin Endocrinol Metab 93:1398-1401

30. Garg RK (2002) Subacute sclerosing panencephalitis. Postgrad Med J 78:63-70

31. Kiessling WR, Hall WW, Yung LL, Ter M V (1977) Measlesvirus-specific immunoglobulin-M response in subacute sclerosing panencephalitis. Lancet 1:324-327

32. Hamill RJ, Baughn RE, Mallette LE, Musher DM, Wilson DB (1986) Serological evidence against role for canine distemper virus in pathogenesis of Paget's disease of bone. Lancet 2:1399

33. Gordon MT, Bell SC, Mee AP, Mercer S, Carter SD, Sharpe PT (1993) Prevalence of canine distemper antibodies in the pagetic population. J Med Virol 40:313-317

34. Basle M, Kouyoumdjian S, Pouplard A, Rebel A, Filmon R (1983) [Paget's bone disease. preliminary serological study]. Pathol Biol 31:41-44

35. Morgan-Capner P, Robinson P, Clewley G, Darby A, Pettingale K (1981) Measles antibody in Paget's disease. Lancet 1:733

36. Langston AL, Campbell MK, Fraser WD, MacLennan GS, Selby PL, Ralston SH (2010) Randomised trial of intensive bisphosphonate treatment versus symptomatic management in paget's disease of bone. J Bone Miner Res 25:20-31
37. Tan A, Goodman K, Walker A, Hudson J, MacLennan GS, Selby PL, Fraser WD, Ralston SH, for the PRISM-EZ investigators (2017) Long-term randomized trial of intensive versus symptomatic management in Paget's disease of bone: the PRISM-EZ study. J Bone Miner Res. doi:10.1002/jbmr.3066

38. Visconti MR, Langston AL, Alonso N, Goodman K, Selby PL, Fraser WD, Ralston SH (2010) Mutations of SQSTM1 are associated with severity and clinical outcome in Paget's disease of bone. J Bone Miner Res 25:2368-2373

39. Kurihara N, Hiruma Y, Yamana K, Michou L, Rousseau C, Morissette J, Galson DL, Teramachi J, Zhou H, Dempster DW, Windle JJ, Brown JP, Roodman GD (2011) Contributions of the measles virus nucleocapsid gene and the SQSTM1/p62(P392L) mutation to Paget's disease. Cell Metab 13:23-34

40. Kallajoki M, Hyypia T, Halonen P, Orvell C, Rima BK, Kalimo $\mathrm{H}$ (1991) Inclusion body myositis and paramyxoviruses. Hum Pathol 22:29-32

41. Sheshberadaran H, Norrby E, McCullough KC, Carpenter WC, Orvell C (1986) The antigenic relationship between measles, canine distemper and rinderpest viruses studied with monoclonal antibodies. J Gen Virol 67(Pt 7):1381-1392

42. Orvell C, Norrby E (1980) Immunological relationships between homologous structural polypeptides of measles and canine distemper virus. J Gen Virol 50:231-245

43. Rosenblatt S, Eizenberg O, Ben-Levy R, Lavie V, Bellini WJ (1985) Sequence homology within the morbilliviruses. J Virol 53:684-690

44. Sanchez A, Banerjee AK, Furiuchi Y, Richardson MA (1986) Conserved structures among the nucleocapsid proteins of the paramyxoviridae: complete nucleotide sequence of human parainfluenza virus type 3 NP mRNA. Virology 152:171-180

45. Stephenson JR, ter Meulen V (1979) Antigenic relationships between measles and canine distemper viruses: comparison of immune response in animals and humans to individual virusspecific polypeptides. Proc Natl Acad Sci USA 76:6601-6605

46. Roodman GD, Windle JJ (2005) Paget disease of bone. J Clin Invest 115:200-208

47. Albagha OM, Visconti MR, Alonso N, Wani S, Goodman K, Fraser WD, Gennari L, Merlotti D, Gianfrancesco F, Esposito T, Rendina D, Di SM, Isaia G, Brandi ML, Guisti F, Del PinoMontes J, Corral-Gudino L, Gonzalez-Sarmiento R, Ward L, Rea SL, Ratajczak T, Walsh JP, Ralston SH (2013) Common susceptibility alleles and SQSTM1 mutations predict disease extent and severity in a multinational study of patients with Paget's disease. J Bone Miner Res 28:2238-2246 